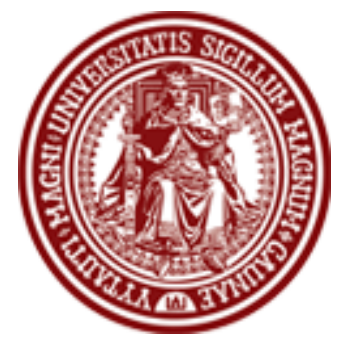

BALTIC JOURNAL OF LAW \& POLITICS

VOLUME 3, NUMBER 2 (2010)

ISSN 2029-0405

http://www.versita.com/science/law/bjlp

Cit.: Baltic Journal of Law \& Politics 3:2 (2010): 26-39

DOI: $10.2478 / \mathrm{v} 10076-010-0009-5$

\title{
STATE OF EXCEPTION AND JUDICIAL POWER
}

\author{
Vaidotas A. Vaičaitis \\ Associate Professor; Dr \\ Vilnius University Faculty of Law (Lithuania) \\ Contact information \\ Address: Sauletekio str. 9-405, LT-10222, Lithuania \\ Phone: (+370 5) 2366175 \\ E-mail address: vaidotas1@hotmail.com
}

Received: July 28, 2010; reviews: 2; accepted: November 26, 2010.

\begin{abstract}
The article deals with the concept of the state of exception in judicial reasoning. Two cases from the European Court of Human Rights together with some case law of the Lithuanian Constitutional Court are examined. The author presents three examples of a possible state of exception from particular case law: i) state of emergency, ii) the concept of transitional democracy and iii) economic crisis. The primary goal of the article is to try to define the boundaries of judicial competence in dealing with the phenomenon of state of exception, which traditionally falls within the competence of executive power. The article argues that the attitude towards this problem in case law has changed a lot during the past couple of decades. Although the court usually does not question the need of Government's announcement of particular state of exception (e.g. state of emergency or economic crisis), the judiciary has attributed to itself rather large discretion to examine whether a particular "exceptional" measure is proportional. According to the examined case law, so-called "primary" human rights (e.g. one's right to life, dignity etc.) as opposed to "secondary" rights (eligibility or economic rights) are usually treated as "absolute" rights and may not be infringed upon even during a state of exception. The Ždanoka judgment is here presented, because the vulnerability of the Latvian political system was treated as a certain exception, justifying some deviation from the common standard of safeguard of one's eligibility rights. The paper also examines recent cases of the Lithuanian Constitutional Court concerning diminished social-economic rights during economic crisis.
\end{abstract}




\section{KEYWORDS}

State of exception, state of emergency, economic crisis, human rights, judicial power, European Court of Human Rights, the Constitutional Court of the Republic of Lithuania 


\section{INTRODUCTION}

After World War II the importance of judicial power greatly increased in European democracies. The creation of European courts and national constitutional courts increased this importance even more. These courts helped a great deal in changing the European (Continental) traditional attitude towards judges as purely obedient servants of legislative and executive power. Former positivistic attitude towards judicial power "contributed" very much in raising authoritarian regimes in twentieth-century Europe. Therefore, the creation of an independent and competent judicial corpus was one of the main transition requirements for reestablished Central-Eastern European democracies at the end of the century.

A state of exception is surely one of the most interesting phenomena that overlaps with political science, sociology and law. "State of exception" in this paper primarily means a certain force majeure, when the execution of ordinary laws and human rights standards might be suspended by executive or legislative decision. Everyone knows the sentence that "there are no rules without exceptions". This is precisely what concerns the law, which is related with different kind of rules. During the last years legal and political science has mostly focused on the executive and legislature in dealing with the matter of state of exception, for they are the most important players in this field. Nevertheless, I will try to deal with the role that judicial power plays in determining the boundaries of the/a state of exception. Major national constitutions in contemporary democratic states regulate certain cases of state of exception: martial law and state of emergency are well known examples. For instance, the Lithuanian Constitution (Art. 144) gives the Parliament and the President discretion to proclaim a state of emergency. The application of various human rights is to be suspended, when martial law is in force or during the time of the state of emergency according to the Art. 145-C. Thus the main issue of this paper is to discuss the margins of judicial competence in the case of state of exception in particular legal systems. Among the examples of state of exception I would like to choose not only state of emergency, but also a concept of transitional democracy and even economic crisis. 


\section{STATE OF EMERGENCY IN THE CASE OF IRELAND V. UK (ECTHR,} 1978)

The first example which I would like to examine in this paper concerns the state of emergency in the UK during the crises of terrorism in the 1970s. From 1971 to 1975 the British government in Northern Ireland exercised a so-called "(temporary) extrajudicial deprivation of liberty" in order to prevent and fight the most violent terrorism campaign. These "extrajudicial powers" included the possibility of arrest without a warrant, preventive detention up to 28 days (without a right to appeal), collective internment and so called "five interrogation techniques", including wall standing, hooding, subject to noise, deprivation of sleep, food and drink.

Article 15 of the European Convention ${ }^{1}$ provides the possibility of certain derogations from the safeguard of human rights. It reads as follows: "In time of war or other public emergency threatening the life of the nation any High Contracting Party may take measures derogating from its obligations under this Convention to the extent i) strictly required by the exigencies of the situation, ii) provided that such measures are not inconsistent with its other obligations under international law." Therefore, firstly, the ECtHR in the case of Ireland $v$. the United Kingdom ${ }^{2}$ needed to decide whether the UK's decision to proclaim a state of emergency in Northern Ireland was not arbitrary and fell within the meaning of "threatening the life of the nation" and "exigency of the situation" under the Article 15 of the Convention. The European Court of Human Rights decided affirmatively to this question, despite the opposite allegations of the Irish Government. The Court reaffirmed its previous case law concerning the interpretation of Article 15 (see judgment of 23 July 1968 on the merits of the "Belgian Linguistic" case, Series A no. 6, p. 35, para. 10 in fine; Handyside judgment of 7 December 1976, Series A no. 24, p. 22, para. 48). Therefore, according to the court, it falls to each Contracting State, with its responsibility for "the life of [its] nation", to determine whether that life is threatened by a "public emergency" and, if so, how far it is necessary to go in attempting to overcome this emergency. Moreover, the Court was of the opinion that by reason of their direct and continuous contact with the pressing needs of the moment, the national authorities are in principle in a better position than the international judge to decide both on the presence of such an emergency and on the nature and scope of derogations necessary to avert it.

\footnotetext{
1 Convention for the Protection of Human Rights and Fundamental Freedoms and its Protocols, 4/11/1950, CETS No. 005 // available through the database http://www.echr.coe.int.

${ }^{2}$ Ireland $v$. the United Kingdom, ECtHR Judgment of 18 January 1978 //

http://cmiskp.echr.coe.int/tkp197/portal.asp?sessionId=57470837\&skin=hudoc-en\&action=request (accessed July 15, 2010).
} 
Nevertheless according to the Court, the States do not enjoy an unlimited power in this respect. The Strasbourg Court, which is responsible for ensuring the observance of the States' engagements, is empowered to rule on whether the States have gone beyond the "extent strictly required by the exigencies" of the crisis (Lawless judgment of 1 July 1961). Therefore, the Court was of the opinion that this wide domestic margin of appreciation may be nevertheless accompanied by certain supervision of ECtHR. However, the Court in this case decided that the latter interrogation techniques as applied by the UK constitute "inhuman and degrading treatment" establishing a breach of Article 3 of the European Convention. According to the Court, the Convention prohibits in absolute terms torture and other inhuman or degrading treatment or punishment, irrespective of the victim's conduct and it makes no provision for exceptions and derogation therefrom, even in the event of a "public emergency threatening the life of the nation". This reasoning may be grounded also relying on Article 15 of the Convention, according to which no derogations from Articles 2 (one's right to life), 3 (protection from torture), 4 (prohibition of slavery) and 7 (nulla poena sine lege) shall be made even in time of war or other public emergency.

From the example of this case we see that the Strasbourg Court is rather reluctant in questioning the need of national state of emergency, leaving it in the hands of the discretion of particular national legislative and executive authorities. Nevertheless, the Court thinks that there are certain human rights (such as, for instance, the right against torture, i.e. against the inhuman and degrading treatment and punishment) that should be treated as "absolute rights" and may not be violated even during a state of emergency.

\section{THE CONCEPT OF "TRANSITIONAL DEMOCRACY" AS A STATE OF EXCEPTION IN CASE OF ŽDANOKA V. LATVIA (ECTHR, 2006)}

This section of the article will relate an interesting case on lustration legislation in Latvia. Firstly I need to say that lustration legislation in Latvia in certain aspects is stricter than that of Lithuania. In Latvia there is an eligibility ban to stand as a candidate in parliamentary elections for those who "actively participated" in the Communist Party after January 13, 1991. In Lithuania there are no similar limits on the electoral rights of former communists. Instead, according to Lithuanian electoral legislation there is only one requirement, namely, to issue a statement on one's electoral political publicity during the electoral campaign, if (s)he was a KGB agent. 
The European Court established the following in this case, ${ }^{3}$ according to historical facts: on January 13,1991, the Soviet army attempted a coup d'etat in Lithuania and Latvia. In April 1990 Mrs Ždanoka was elected to the Latvian Communist Party's (CPL) Central Committee. On August 23, 1991, the Latvian Supreme Council declared the CPL unconstitutional. According to the Latvian Lustration legislation, an unlimited eligibility ban was introduced for those who "actively participated" in the activities of the CPL after January 13, 1991. The Latvian Constitutional Court has affirmed the constitutionality of this piece of legislation (in the judgment of August 30, 2000). It is also important that Latvian courts established that Mrs Ždanoka had "actively participated" in the activities of the Latvian Communist Party after January 13, 1991. Relying on these findings she was denied registration for the parliamentary elections in the Latvian Republic. After she exhausted all national measures to fight with this ban to stand as a candidate, she applied to the European Court of Human Rights. On June 17, 2004 the European Court decided that Latvia has violated Article 3 of Protocol No. 1 and Article 11 of the Convention. ${ }^{4}$ Then Latvia applied to the Grand Chamber, which in a March 16, 2006 judgment decided (13 votes to 4) that there was no breach of the Convention.

The Court in the last judgment stated inter alia that

While such a measure [unlimited eligibility ban for former communists] may scarcely be considered acceptable in the context of one political system, for example in a country which has an established framework of democratic institutions going back many decades or centuries, it may nonetheless be considered acceptable in Latvia in view of the historico-political context which led to its adoption and given the threat to the new democratic order posed by the resurgence of ideas which, if allowed to gain ground, might appear capable of restoring the former regime [133]. ${ }^{5}$

It means that the "historico-political context" - in this case, the vulnerability of Latvia's political system after the re-establishment of the democracy and independence from totalitarian soviet regime in 1991 - may change the common practice of the application of human rights prescribed by the European Convention.

3 Ždanoka v. Latvia, ECtHR Judgment of 16 March $2006 / /$

http://cmiskp.echr.coe.int/tkp197/view. asp?item =1\&portal=hbkm\&action=html\&highlight $=58278 / 00 \&$ se ssionid=57471546\&skin=hudoc-en (accessed July 15, 2010).

${ }^{4}$ Article 3 of Protocol No. 1 states: "The High Contracting Parties undertake to hold free elections at reasonable intervals by secret ballot, under conditions which will ensure the free expression of the opinion of the people in the choice of the legislature." And an Article 11 of the Convention says: "1. Everyone has the right to freedom of peaceful assembly and to freedom of association ... 2. No restrictions shall be placed on the exercise of these rights other than such as are prescribed by law and are necessary in a democratic society in the interests of national security or public safety, for the prevention of disorder or crime, ... or for the protection of the rights and freedoms of others. This Article shall not prevent the imposition of lawful restrictions on the exercise of these rights by members of the armed forces, of the police or of the administration of the State" (ibid.).

${ }^{5}$ Ibid. 
Here we see that one's electoral right to stand as a candidate for parliamentary elections is considered by the Court not as an "absolute" right (in comparison with one's right against inhuman treatment and punishment) and its application might be rather flexible depending on the particular political system. Therefore, eligibility rights are considered by the European Court to be "secondary rights" and are not protected on the same level as "primary rights", defined in Articles 2 or 3 of the Convention. In other words, the vulnerability of a particular political system might cause a certain exception from common protection practice of European eligibility rights. In this case we see that a "state of exception" in judicial reasoning might mean not only the particularity of the current situation (e.g. a current state of emergency), but also a certain historical experience in the country's past. This does not mean only flexibility of legal rules, but it might also mean that these rules should be interpreted in light of the general principles of justice and reasonableness. And application of these principles in practise recognises some exceptions from the common meaning of one's electoral rights.

\section{ECONOMIC CRISIS AS A STATE OF EXCEPTION IN JUDICIAL} REASONING

The 2008-2010 economic crisis and the various and differing reactions to it inspired me to look at this phenomenon as a certain state of exception for the Government's legal and political actions. In case law of the Lithuanian Constitutional Court, economic crisis as a certain force majeure appeared already in a November 25, 2002 judgement, where the constitutionality of reduction of size of public pensions for the elderly was examined. ${ }^{6}$ In the year 2000 the newly formed government in Lithuania decided to adopt such an unpopular measure following the 1998 economic crisis in Russia, which deeply influenced the Lithuanian financial market. After incomes to the public social security fund were dramatically reduced, the Lithuanian government decided to reduce public pensions for the elderly not across the board, but only for those who had other financial recourses - most notably for "working pensioners". The Court examining the constitutionality of this reduction stated in this case that "there may occur such an extreme situation in the state (economic crisis, natural disaster etc.), when it is impossible to accumulate enough funds for the payment of the pensions". Therefore, the Court in principle agreed with the government that in such extraordinary cases public pensions for the elderly may be reduced, but only "to the extent that it is necessary to ensure vitally important interests of society and protect other constitutional values" and

\footnotetext{
6 Judgment of the Constitutional Court of the Republic of Lithuania of 25 November 2002, Official
} Gazette, 2002, no. 113-5057. 
that these exceptional measures (reduction of public pensions for the elderly) should only be "provisional". Relying on the principle of legitimate expectations, in this judgment the Constitutional Court came to the conclusion that such a reduction unfairly discriminated against "working pensioners", to whom a particular public pension was already granted and which had already begun to be paid out, and therefore according to the Court this reduction was anti-constitutional. The outcome of this judgment was that the government not only decided to restore the reduced pensions, but also promised "to compensate" the difference which would appear in the future due to this reduction. The reasoning of this judgment received criticism, namely, that the Court in this judgment disregarded the principle of social solidarity on which the entire public social security system is to be based and that the principle of legitimate expectations (concerning the size of elderly pensions) was unfairly treated as an absolute principle. ${ }^{7}$ The ratio of this judgment "between the lines" meant that the Court did not recognize the Lithuanian economic situation in 2000-2002 as an "economic crisis", which as a state of exception could have led to the possibility of a reduction of pensions. Therefore, from this judgment it was unclear whether, according to the Court, the government has an absolute discretion (freedom) in deciding the means and size of the reduction of social payments after declaring economic crisis or if there should be any constrains for this discretion. Here it must be said that the Court, reasoning that such a reduction was against the Constitution, not only formulated the requirement of "provisional character" of this reduction, but also decided to link this anti-constitutionality with breach of one's right to property. This link (of reduction of social payments) with breach of one's right to property and the government's populist reaction after the November 25, 2002 judgment helped the Court in a judgment on December 3, 2003 to develop the idea that the Constitution indeed requires that such a reduction of social payments should be compensated, when the economic crisis finally comes to an end. ${ }^{8}$ Therefore, dealing with the possibility of the government reducing in size or even entirely abolishing some sort of state pensions, ${ }^{9}$ in this judgment the Court

\footnotetext{
7 See e.g. Vaidotas A. Vaičaitis, "What Was Decided by Lithuanian Constitutional Court in Favour of Pensioners," Teise 49 (2003).

8 Judgment of the Constitutional Court of the Republic of Lithuania of 3 December 2003, Official Gazette, 2003, no. $115-5221$.

${ }_{9}$ Article 52 of the Lithuanian Constitution mentions only two types of pensions: elderly and disability pensions. Nevertheless according to ordinary legislation in Lithuania besides the said system of ordinary social security pensions (which from public social security fund is to be granted to practically every Lithuanian citizen reaching the particular age) there exist also different types of so called "the state pensions" (valstybine pensija), which from state budget are paid only to certain extent of people, supposed to have particular merits for the society: former famous statesmen, former public officers (e.g. policemen, judges etc.), famous artists, sportsmen and also some groups of people, which have been victims of the soviet regime, II WW etc. The state pension might be granted and paid irrespectively to the fact, whether a person gets the social security pension or not, therefore it is possible that the same person may be granted a social security (e.g. elderly or disability) pension together with the state pension.
} 
stated that in doing so the government should create a "mechanism of just compensation".

After nearly decade, at the end of 2009, facing a new worldwide economic crisis and problems with drastic reduction of incomes to the state budget and public social security fund, the Lithuanian government decided to reduce all public social aid including social security and state pensions relying on the Constitutional Court's concept of economic crisis as a certain state of exception from the common meaning of one's constitutional social rights. Adopting a particular provisional law in its preamble, the Seimas (Parliament) made reference to the case law of the Constitutional Court and expressis verbis mentioned that Lithuania is facing an economic crisis. ${ }^{10}$ In an April 20, 2010 decision, the Court found that the economic crisis should be "officially announced", but it refused to answer the question as to whether the economic crisis should be officially affirmed and each year reaffirmed by particular decree of the government. ${ }^{11}$ The Constitutional Court in this decision "between the lines" agreed with the government that this time Lithuania faces a real economic and financial crisis and that the Government may reduce its social security guaranties that were earlier promised to the people. The Court also repeated its earlier statement that this reduction should be provisional, i.e. only for the period of one year. According to the Court, the government and the Parliament, planning and adopting the state budget of each successive year, should examine whether the country's economic situation has improved and whether it is already possible to raise the previously reduced public salaries and social payments.

The Court recalled that this reduction of salaries and pensions should be proportional, i.e. the proportions of size of previous salaries and pensions should be kept and this reduction should not be below the dignity and vital needs of the human being. The Court here also repeated its controversial statement that even during an economic crisis social security pension should not be reduced proportionally more for "working pensioners" than for those who do not have incomes other than public pension. It was already said that the Lithuanian Constitution (Art. 52) mentions only two types of social security pensions: elderly and disability pensions. Therefore the Court stated that during the economic crisis the entire social security system might be changed, but only those pensions not mentioned in the Constitution (e.g. the state pensions) may be abolished. According to the Court, those pensions that are not provided in the Constitution may be reduced proportionally more than elderly or disability pensions. In the same

10 See Socialiniu išmoku perskaičiavimo ir mokejjimo laikinasis istatymas (Provisional Law on Reevaluation of Social Payments), Official Gazette, 2009, no. 152-6820.

11 Decision of the Constitutional Court of the Republic of Lithuania of 20 April 2010, Official Gazette, 2010, no. 46-2219. 
case the Court repeated that such a reduction of social security payments should be "compensated" later on in reasonable time, when economic crisis will come to the end. In summary, in this judgment the Court treated elderly and disability pensions (which are expressis verbis proscribed in the Constitution) differently in comparison with the state pensions. The Court allowed the reduction of the size of the latter pensions more than the former or even them to be abolished during economic crisis. This difference was also related with the idea of their compensation. According to the Court, i) the compensation of the state pensions should be necessary only if the reduction of it is to be "large" (dideliu mastu) and ii) that this compensation (of reduced size of state pensions) may be smaller than that of reduction of elderly or disability pensions.

Therefore, the Constitutional Court here agreed that the social security system in principle could be restructured, by, for instance, abolishing state pensions (for they are not specified in the Constitution); but, the Court requires a "just compensation" (sic!) for such a change. It is unclear just what the phrase "a just compensation" of reduced (or even abolished) pensions means. This terminology comes from the Court's idea that social security payments should be treated as one's right to property (ownership) and that legitimate interests of the particular receiver of any social security aid should be treated as an absolute principle, disregarding the fact that the size of the pension or other social payments might be fixed by the government unfairly or arbitrarily, relying just on populist promises before the elections. If we are of the opinion that this compensation should mean that after an economic crisis the government should compensate the exact difference of reduced pensions, which lasted throughout the time of the crisis, it would mean that the future government would never create an appropriate social security system, for that burden would be too heavy for the working part of the society. Therefore, this idea of "just compensation" should be interpreted not in the context of one's property rights, but in the context of social solidarity, on which the entire social security system is to be based in a democratic society. In other words, the idea of just compensation should be interpreted not only in the context of corrective justice, but also in the context of distributive justice as lord Stein formulated it in McFarlane v. Tayside Health Board (House of Lords, 1999). ${ }^{12}$ It means that this "just compensation" should not be understood only in monetary terms.

In the successive judgment of June 29, 2010, the Lithuanian Constitutional Court affirmed and further developed its previously mentioned controversial ratio

12 McFarlane v. Tayside Health Board, House of Lords, 25 November 1999, All English Law Reports (15 December 1999). 
concerning the government's discretion to reduce public payments. ${ }^{13}$ In this case the Court examined the constitutionality of the reduction of size of the judges' state pension (valstybine teiseju pensija), in particular during the economic crisis. The big controversy in this case is that judges of the Constitutional Court needed to examine the constitutionality of the reduction of their own state pensions. In this time the Court factually abolished all provisions of the law, according to which the judges' state pensions were reduced. Relying on the constitutional principle of independence of judiciary (Article 109-2 of the Constitution) the Court here recalled the ratio of its October 22, 2007 judgment, ${ }^{14}$ saying that the judges' state pension should be treated differently than other state pensions in the way that the former pensions may not be entirely abolished (although they are not mentioned directly in the Constitution). Another controversy in this case is that the Court, not renouncing its previous statement that the state pensions during the economic crisis may be reduced proportionally more than social security (elderly and disability) pensions or even entirely abolished, found here that even during the economic crisis the judges' state pension may not be substantially reduced. As concerns the constitutionality of said reduction, the Court found that the reduction in size of the judges' state pensions was anti-constitutional also because the actual reduction of the judges' state pensions should be regarded as "large" and therefore in reducing these pensions the Seimas had an obligation simultaneously to fix a compensation mechanism by the statute of the Parliament and not to charge this task with the government as it was done by the said law of December 9, 2009. Finally, after this judgment the government officially announced that reduction of social security payments for citizen should be "compensated" only when the Lithuanian economy will reach a level at which the pensions and other social security payments could be raised without international loans and not earlier than in 2014.

\section{CONCLUSIONS}

In between the World Wars the famous, controversial German lawyer and philosopher Carl Schmitt wrote that every Constitution must include a clause on a state of emergency as a certain exception (or even dictatorial element) within a democracy. According to Schmitt, this state of exception frees the executive from any legal restraints to its power that would normally apply. Therefore, according to him, sovereignty means the power to decide on the state of exception. Through the state of exception Schmitt justified all types of violence as "legal" (Political

\footnotetext{
13 Judgment of the Constitutional Court of the Republic of Lithuania of 29 June 2010 // http://www.Irkt.It/dokumentai/2010/r100629.htm (accessed July 15, 2010).

${ }_{14}$ Judgment of the Constitutional Court of the Republic of Lithuania of 22 October 2007, Official Gazette, 2007, no. $110-4511$.
} 
Theology). In the case of the authority of Hitler it led to the formulation "the leader defends the law" ("Der Führer schützt das Recht"). On the other hand, under the "soviet democracy" the executive (in fact, the Communist Party) was also using all kind of exceptions from common legal rules, especially through hands of militia and KGB, which have been above the law. Therefore the judicial power in these totalitarian regimes was to be treated only as a modest servant of political power and was deprived from any legal evaluations on the boundaries of such exceptional powers and practices.

In the beginning of the twenty-first century the judicial power in European democracies has much more independence in the state's political structure and therefore much more courage in interpreting legal rules. This also concerns the interpretation of the state of exception. Of course, the executive is still the master on proclamation of a state of exception and therefore the judicial power may act only posteriori here, as it does in all other cases. Judicial power usually does not question the actual need for the proclaiming of a state of exception as announced by the executive (e.g. state of emergency or economic crisis), as we have seen in the case of Ireland $v$. the UK and in the case law of Lithuanian Constitutional Court concerning economic crisis. But, in all three cases (Ireland v. the UK, Ždanoka v. Latvia and rulings of Lithuanian Constitutional court on reductions of size of pensions during economic crisis) we can see that the judiciary may evaluate the proportionality of particular exceptional measures, which might reduce some human rights and establish certain limits on it. In other words, the judiciary already seems to have a right to establish certain boundaries on the executive's discretionary powers concerning the state of exception. For instance, in the case of Ireland $v$. the UK the European Court of Human Rights found that some primary human rights - such as one's right to be protected against torture may not be violated even during a state of emergency. In the Ždanoka case the same Court announced that Latvian executive and legislative power needs a periodical evaluation of the Latvian political situation and a re-examining of the question as to whether the unlimited eligibility ban for former high Communist officers is still needed. As concerns the executive's decision on the reduction in the size of pensions, the Lithuanian Constitutional Court decided that even during the economic crisis the Lithuanian government is not absolutely free to reduce the size of different social payments, for these reductions should be i) provisional, they have to be ii) proportional according to their previous size, and they should be iii) compensated in rational time after the end of economic crisis.

I would not deny the possible judicial competence per se in the sphere of examination of proportionality of particular means of state of exception. But we 
should not exaggerate this - the court of justice should be very accurate in dealing with this matter. Let me clarify my point, relying on the above-mentioned case law:

1. I do agree with the outcome of the case of Ireland $v$. the UK, when the court decided that primary human rights (one's right against torture in this case) should be protected during a state of emergency in the same way as in ordinary time. But I am not so sure we could arrive at the same conclusion if we deal with the most extreme example of the state of exception - namely, the state of war. Article 15-2 itself of the European Convention recognizes that derogation from protection of one's right to life may be applied during "lawful acts of war". In such a situation a court of justice (especially the European court) would have a big problem examining the proportionality of a particular measure taken by an executive during the war.

2. With the Ždanoka case, lustration legislation is very much related to political situation in the country. For this reason the judge in Strasbourg may have great difficulty understanding the real political situation in country $X$ and its vulnerability and need for a particular lustration policy after the fall of an authoritarian regime, for instance, or the ban of a certain political party or limitation of eligibility rights for some former officers of an undemocratic regime. In my opinion, the 2006 judgment of the Grand Chamber of the Strasbourg Court was right when it decided not to intervene in this delicate matter.

3. With respect to case law of the Lithuanian Constitutional Court on the reduction of social payments during economic crisis, I think that the Lithuanian constitutional judge was not right to place on the government such large constraints on so-called economic crisis legislation, when she found that the government needs to compensate reduced pensions in the future. Such a strict and direct intervention of a judge into the country's economic life (without real economic means to implement this requirement) may lead the country to the next economic and even socio-political crisis and to a very unfortunate decline in prestige and authority of the judiciary.

\section{BIBLIOGRAPHY}

1. Convention for the Protection of Human Rights and Fundamental Freedoms and its Protocols. 4/11/1950, CETS No. 005 // available through the database http://www.echr.coe.int.

2. Decision of the Constitutional Court of the Republic of Lithuania of 20 April 2010. Official Gazette, 2010, no. 46-2219. 
3. Ireland $v$. the United Kingdom. ECtHR Judgment of 18 January 1978 // http://cmiskp.echr.coe.int/tkp197/portal.asp?sessionId=57470837\&skin=hud oc-en\&action=request (accessed July 15, 2010).

4. Judgment of the Constitutional Court of the Republic of Lithuania of 22 October 2007. Official Gazette, 2007, no. 110-4511.

5. Judgment of the Constitutional Court of the Republic of Lithuania of 25 November 2002. Official Gazette, 2002, no. 113-5057.

6. Judgment of the Constitutional Court of the Republic of Lithuania of 29 June 2010 // http://www.Irkt.It/dokumentai/2010/r100629.htm (accessed July 15, 2010).

7. Judgment of the Constitutional Court of the Republic of Lithuania of 3 December 2003. Official Gazette, 2003, no. 115-5221.

8. McFarlane v. Tayside Health Board. House of Lords, 25 November 1999. All English Law Reports (15 December 1999): 961-979.

9. Socialiniu išmoku perskaičiavimo ir mokejjimo laikinasis istatymas (Provisional Law on Re-evaluation of Social Payments). Official Gazette, 2009, no. 1526820.

10. Vaičaitis, Vaidotas A. "What Was Decided by Lithuanian Constitutional Court in Favour of Pensioners." Teisé 49 (2003): 124-133.

11. Ždanoka v. Latvia. ECtHR Judgment of 16 March 2006 // http://cmiskp.echr.coe.int/tkp197/view.asp?item =1\&portal=hbkm\&action=ht ml\&highlight $=58278 / 00 \&$ sessionid $=57471546 \&$ skin $=$ hudoc-en (accessed July $15,2010)$. 